\title{
Consumption of red meat, white meat and processed meat in Irish adults in relation to dietary quality
}

\author{
Meadhbh Cosgrove, Albert Flynn and Máiréad Kiely* \\ Department of Food and Nutritional Sciences, University College Cork, Republic of Ireland \\ (Received 10 May 2004 - Revised 28 October 2004 - Accepted 11 January 2005)
}

\begin{abstract}
The aim of the present study was to examine the association of red meat, white meat and processed meat consumption in Irish adults with dietary quality. A cross-sectional study of subjects, randomly selected using the electoral register, estimated habitual food intakes using a $7 \mathrm{~d}$ food diary in a nationally representative sample of 662 men and 717 women (not pregnant or lactating) aged 18-64 years. Consumers were classified into thirds, based on the distribution of mean daily intakes for red meat, white meat and processed meat. The mean intakes of red meat, white meat and processed meat were 51 , 33 and $26 \mathrm{~g} / \mathrm{d}$ respectively, and men consumed significantly more $(P<0 \cdot 001)$ than women for all meat types. In men, red meat consumption was associated with lower $(P<0.001)$ prevalence of inadequacy for $\mathrm{Zn}$, riboflavin and vitamin $\mathrm{C}$ intakes. Increasing processed meat intake was associated with a lower $(P<0 \cdot 01)$ level of compliance with dietary recommendations for fat, carbohydrate and fibre in men. Increasing processed meat consumption was associated with lower $(P<0.01)$ wholemeal bread, vegetables, fruit and fish intakes in men and women. Managerial occupations were associated with lower processed meat intakes. It is important to distinguish between meat groups, as there was a large variation between the dietary quality in consumers of red meat, white meat and processed meat. Processed meat consumption is negatively associated with dietary quality and might therefore be a dietary indicator of poor dietary quality. This has important implications in nutritional epidemiological studies and for the development of food-based dietary guidelines.
\end{abstract}

Red meat: White meat: Processed meat: Dietary recommendations: Micronutrient adequacy

Meat is a nutrient-dense food and meat and meat products are an important source of a wide range of nutrients. However, meat is not a homogeneous food group and the composition of meat varies widely by meat category. The fat content of red meats such as beef $(3 \cdot 5-9.3 \%)$, lamb $(7 \cdot 5-13.3 \%)$ and pork $(3 \cdot 7-10 \cdot 1 \%)$ is higher than that of chicken $(1 \cdot 1-9 \cdot 7 \%)$ and turkey $(2 \cdot 0-6 \cdot 6 \%)$, with processed meat such as burgers and sausages generally having the highest fat content (up to $25 \%$; Chan et al. 1995, 1996). Usually, red meats such as beef and the dark meat of chicken and turkey are better sources of Fe than are white meats such as the light meat of poultry (Chan et al. 1995).

Meat and meat constituents such as its fat profile, protein and $\mathrm{Fe}$ content have been identified as dietary risk factors for CHD (Denke, 1994; Hu et al. 1999), obesity (Lahti-Koski et al. 2002; Schulz et al. 2002) and colorectal cancer (Willett et al. 1990; Giovannucci et al. 1994; World Cancer Research Fund/American Institute for Cancer Research, 1997; Sesink et al. 1999; Key et al. 2004). Recent research, however, highlights that not all meat categories make similar impacts in the development of poor health outcomes. Specifically, red meat and processed meat, but not white meat, have been shown to increase the risk for colon cancer (Willett et al. 1990; Giovannucci et al. 1994; Goldbohm et al. 1994; Navarro et al. 2003).

Evolving trends in nutrition research show that examining dietary patterns rather than individual components of the diet is important in nutritional epidemiology (Pryer et al. 2001; Hu, 2002; Quatromoni et al. 2002). Dietary patterns that include processed meat and red meat have been shown to be associated with overall increased risk of disease including CVD (Hu et al. 2000; Fung et al. 2001; van Dam et al. 2003), colon cancer (Fung et al. 2003), oesophageal cancer (Chen et al. 2002) and type 2 diabetes (van Dam et al. 2002), compared with dietary patterns including poultry.

Meat is a key food group encompassing several important individual meat categories. It is important to study dietary quality for distinct meat categories in nutritional epidemiological studies and for the development of food-based dietary guidelines (Food and Agriculture Organization/World Health Organization, 1998). Previous analysis of meat intake in the Republic of Ireland has shown that there are distinct consumer habits in relation to beef, poultry, burger and sausage intakes (Cosgrove et al. 2005). Few studies have examined dietary quality of subgroups of the population in terms of consumption of individual meat categories. Elmstahl et al. (1999) observed higher intakes of protein, monounsaturated fat, $\mathrm{Zn}$ and thiamine but lower intakes of carbohydrates, vitamin $\mathrm{C}$ and fibre with increasing meat intake. No study to date has examined dietary quality in relation to individual meat categories. The aim of the present study was to examine red meat, white meat and processed meat consumption Irish adults aged 18-64 years in relation to dietary quality. 


\section{Methodology}

Survey sample and design

A detailed account of the sampling procedure and design of this study has been published elsewhere (Kiely et al. 2001). Briefly, the current data were collected as part of the North/South Ireland Food Consumption Survey, a cross-sectional study that was carried out from 1997 to 1999 (Irish Universities Nutrition Alliance, 2001). Men and women were selected at random using the electoral register as the sampling frame and an information leaflet and letter were posted to each individual. This was followed by a visit from a member of the survey team and participation was invited. Food intake was measured in $63 \%$ of the eligible sample (aged between 18 and 64 years, not pregnant or lactating). Analysis of the survey sample ( $n$ 1379: 662 men, 717 women) in terms of sex, age, socio-economic status and education level showed it to be representative of both the Irish and Northern Irish adult populations at that time. Moreover, non-response, investigated in terms of sex, age and geographical location, was found to be unbiased (Kiely et al. 2001). The present analysis is based on the survey database of 958 adults (475 men, 483 women) from the Republic of Ireland only. Table 1 shows the characteristics of the survey sample in terms of sex, age, socio-economic status and education level, compared with sociodemographic statistics from the Republic of Ireland Census '96 (Central Statistics Office, 1997, 1998). The current sample shows under-representation of the 18-35-year age group as a higher proportion of 18-35-year-olds were not contactable compared with older adults. The sample also had an over-representation of people with tertiary education compared with the census; however, the census also includes $>65$-year-olds, of whom a smaller percentage has tertiary education. Furthermore, the current survey included a broader range of tertiary qualifications including technical college and city and guilds qualifications.

\section{Food and nutrient intakes}

Food and beverage intake data were collected using a $7 \mathrm{~d}$ estimated food diary, and precise details on the methods used are available (Harrington et al. 2001b). Briefly, the research nutritionist made four visits to the respondent during the $7 \mathrm{~d}$ period: to train the respondent in keeping the diary; to check for completeness in

Table 1. Age, social class occupations and education levels of adults from the Republic of Ireland

\begin{tabular}{|c|c|c|}
\hline & $\begin{array}{l}\text { Present sample } \\
\quad(n 958)\end{array}$ & Census ' $96^{*}$ \\
\hline \multicolumn{3}{|l|}{ Age category (\%) } \\
\hline $18-35$ years & $35 \cdot 1$ & $46 \cdot 0$ \\
\hline $36-50$ years & $39 \cdot 6$ & $33 \cdot 0$ \\
\hline $51-64$ years & $25 \cdot 4$ & $20 \cdot 0$ \\
\hline \multicolumn{3}{|l|}{ Social class occupations (\%) } \\
\hline Professional, managerial and technical & $42 \cdot 7$ & $37 \cdot 9$ \\
\hline Non-manual & $17 \cdot 6$ & $22 \cdot 9$ \\
\hline Skilled manual & $19 \cdot 4$ & $20 \cdot 1$ \\
\hline Semi-skilled and unskilled & $15 \cdot 3$ & $19 \cdot 1$ \\
\hline \multicolumn{3}{|l|}{ Education level attained (\%) } \\
\hline Primary & $18 \cdot 5$ & $22 \cdot 6$ \\
\hline Intermediate & $20 \cdot 4$ & $22 \cdot 0$ \\
\hline Secondary & $23 \cdot 2$ & $31 \cdot 2$ \\
\hline Tertiary & $35 \cdot 3$ & $23 \cdot 7$ \\
\hline
\end{tabular}

* Republic of Ireland Census '96 (Central Statistics Office, 1997, 1998).

For details of survey samples and design, see p. 934-935. recording food and drink consumption; to clarify details regarding specific food descriptors and quantities; to encourage completion of the study.

In the food diary, respondents were asked to provide detailed information regarding the types and amounts of all foods. For meat specifically, a description of the cut/joint, the cooking method and brand names (where relevant) and details of trimming and leftovers were included. Respondents were also asked to provide detailed recipe information, where they recorded details of meat included in recipes. Data were also collected on the time of each eating/drinking occasion, the respondent's definition of each eating/drinking occasion (e.g. morning snack, lunch, etc.) and the location of the preparation or source of the meal or snack consumed (e.g. home, work, takeaway, etc.). Self-administered questionnaire data were also obtained on sociodemographic factors and health and lifestyle parameters.

On the basis that different foods are best quantified using different methods and that some methods of quantification are more precise than others, a hierarchical approach to quantify meat among other foods and drinks was developed. Meat and meat products were quantified using specific methods according to a quantification protocol (Harrington et al. 2001b). If it was not possible to quantify meat with a method on the first level of hierarchy, a subsequent method was used.

(1) Thirty-eight per cent of meat and meat products were quantified using a data set of average portions collected from deli counters and takeaway restaurants.

(2) Twenty-one per cent were quantified using twelve colour photographs of fresh meat and meat dishes, in a food atlas of commonly consumed foods in Ireland (J. Robson, un publish data).

(3) Eighteen per cent were quantified using average portion sizes (Ministry of Agriculture, Fisheries and Food, 1997).

(4) Ten per cent were estimated by the researcher based on her knowledge of the respondent's eating patterns.

(5) Six per cent were quantified from average portion sizes recommended by the manufacturer on the label, including franchised fast foods and chilled and frozen foods.

(6) Six per cent were quantified by the researcher weighing a typical portion of meat consumed by the respondent.

Nutrient intakes were calculated from the $7 \mathrm{~d}$ diaries using WISP ${ }^{\odot}$ (Tinuviel Software, Warrington, UK), which included McCance and Widdowson's The Composition of Foods, fifth edition (Holland et al. 1995) and supplemental volumes (Holland et al. 1988, 1989, 1991, 1992, 1993, 1996; Chan et al. 1994, 1995, 1996. Some 993 foods were added to this database to include new food products, recipes (of which 230 contained meat), nutritional supplements and manufacturer's data for generic Irish foods that were commonly consumed. Overall, 3060 different food codes were recorded, of which 742 were meat codes, including 422 composite food codes and 320 codes for meats consumed as individual portions.

\section{Meat intakes}

In the present analysis, meat intakes were estimated from the database using disaggregated composite foods to exclude the contributions from non-meat components. Previously, analysis of meat intakes has shown that failure to disaggregate composite 
foods substantially overestimates meat intakes by approximately $40 \%$ (Cosgrove et al. 2000).

Composite foods that contained meat were predominantly pasta dishes (e.g. bolognaise and lasagne), stews, cottage/shepherds pies, burger sandwiches (i.e. in a bun), sausage rolls, rice dishes (e.g. curry, stir-fry and sweet and sour), and a small number of composite foods that normally contain a small amount of meat but are typically excluded from meat intake analysis (e.g. quiche lorraine, pizza). The weight of the meat only in each composite food was calculated. Meat was quantified in the majority of composite foods $(75 \%)$ using recipe details. Any weight losses during cooking were accounted for. McCance and Widdowson's The Composition of Foods, fifth edition (Holland et al. 1995) and Meat Products and Dishes (Chan et al. 1996) were used to quantify the meat in $13.5 \%$ of composite foods, $8.5 \%$ were quantified using manufacturer's weights, $2 \%$ were quantified from product information from fast-food franchises (e.g. McDonalds, Burger King) and extra data collected by fieldworkers from independent takeaway restaurants, and $1 \%$ were estimated based on similar composite foods consumed.

The present analysis is based on the consumption of three independent meat groups: (i) red meat (40\% of all meat), including beef (including veal), lamb and pork; (ii) white meat $(21 \%$ of all meat), including chicken and turkey; (iii) processed meat (16\% of all meat), including beefburger, pork sausage, continental-style sausage (including salami and frankfurter) and minced beef. The remaining $23 \%$ of all meat recorded included bacon, duck, pheasant, rabbit, venison, liver, kidney, white and black pudding, ham, luncheon meat and corned beef, and was not included in the current analysis.

\section{Adequacy of micronutrient intakes}

The average requirement (AR), as estimated by the Scientific Committee for Food (1993), was used as a cut-point to estimate the proportion of population subgroups with inadequate micronutrient intakes for men and women separately. The AR is the daily intake value estimated to meet the requirement, as defined by a specified indicator of adequacy, in $50 \%$ of a life-stage or gender group (Food and Nutrition Board, 1997). The percentage of the population with a mean daily nutrient intake below the AR was taken as an estimate of the percentage of the population with inadequate intakes. This cut-point approach using AR has been used previously and was demonstrated favourably under specified conditions (Carriquiry, 1999), most of which were met in this population (Hannon et al. 2001).

\section{Compliance with dietary recommendations}

The Wearne \& Day (1999) method of evaluating population compliance with dietary guidelines of $50 \%$ or more of food energy from carbohydrate, $35 \%$ or less of food energy from fat, $11 \%$ or less of food energy from saturated fat, $13 \%$ or more of food energy from monounsaturated fat and $18 \mathrm{~g}$ or more of NSP, as recommended by the Committee on Medical Aspects of Food Policy (Department of Health, 1991), was used. The maximum size of a subgroup of the population, whose mean intake meets the population dietary recommendations, was calculated. These subgroups are referred to as 'compliers'. To identify the compliers with the fat and saturated recommendation, the mean intake for each individual was ranked in ascending order, the mean intake was calculated by starting with the individual with the lowest mean fat intake and successive individuals were added until the addition of the next individual caused the group mean to exceed the target. For carbohydrate, monounsaturated fat and fibre the same approach was used except that mean intakes for each individual were ranked in descending order, then starting with the highest mean intake successive individuals were added until the addition of the next individual caused the group mean to fall below the target.

\section{Statistical analysis}

Meat intakes were examined by dividing men and women separately into thirds of the distribution, based on the mean daily intake of each meat group in consumers. Thus, the lowest third (for each meat group) represents the low consumers while the highest third represents the high consumers. Data manipulation and statistical analysis were carried out using the Statistical Package for Social Sciences Version 10.0 for Windows ${ }^{\mathrm{TM}}$ (SPSS Inc., Chicago, IL, USA) and Microsoft Excel ${ }^{\mathrm{TM}} 2000$ (Microsoft Corporation, Redmond, WA, USA).

Differences in meat intakes between men and women were compared using independent $t$ tests, and between age groups using one-way ANOVA. Differences in nutrient and food intakes were compared between thirds using analysis of covariance, with age as a covariate. Differences across categorical variables were compared using Pearson's $\chi^{2}$ test. Values of $P<0.01$ were reported as statistically significant (two-tailed).

\section{The effect of under-reporting}

Mean energy intakes increased significantly with increasing red meat and processed meat intakes. Therefore, nutrient and food intakes across thirds of meat intake were examined after adjusting for energy intake (excluding energy from alcohol). As with all dietary surveys, evidence of misreporting of energy intakes has been shown in this survey sample (McGowan et al. 2001). Using the Goldberg cut-off for energy intake:BMR of $<1.05$ (Goldberg et al. 1991), the impact of individuals with questionably low energy intakes was assessed in this sample. The proportion of individuals with energy intake:BMR $<1.05$ was $18 \%$ and this was higher in non-consumers $(20,17$ and $25 \%)$ compared with consumers $(18,18$ and $16 \%)$ of red meat, white meat and processed meat, respectively. In this sample the removal of individuals with very low energy intakes did not change the overall dietary trends associated with red meat, white meat or processed meat consumption. Therefore, the classification of low and high meat consumers includes the entire sample.

\section{Results}

\section{Meat consumption}

Red meat was consumed by $88 \%$ of the population ( $92 \%$ of men and $84 \%$ of women), white meat by $79 \%$ (77\% of men and $81 \%$ of women) and processed meat by $79 \%$ ( $82 \%$ of men and $75 \%$ of women). The majority ( $83 \%$ ) of eating occasions that included red meat, white meat or processed meat occurred in the respondent's home. The main source of red meat, white meat and processed meat throughout the day was at the main meal (as defined by the subject), 


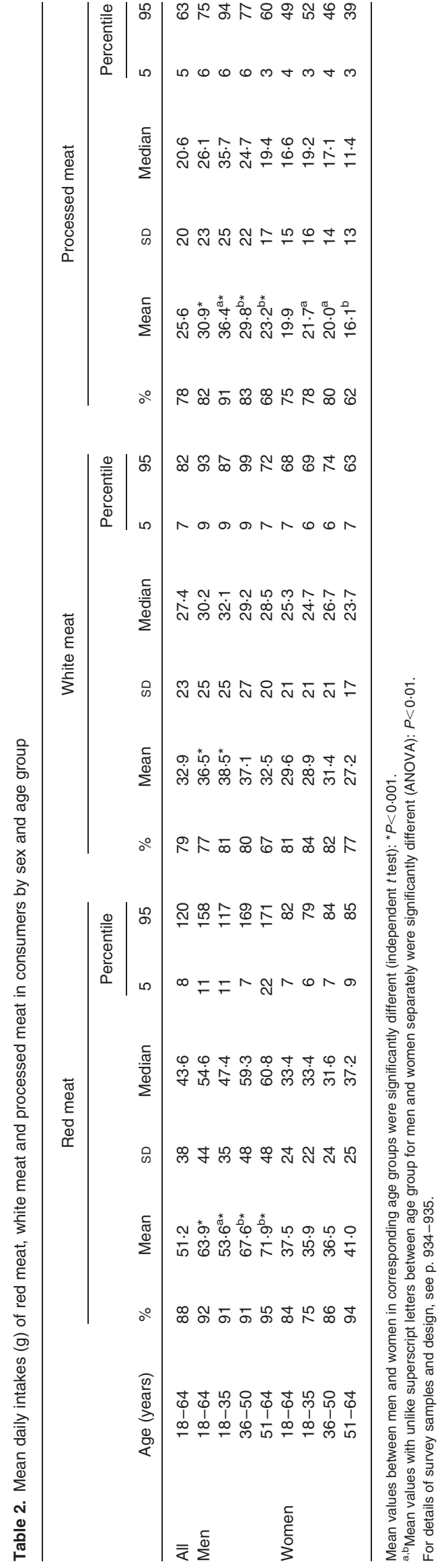

either at dinner $(127 \cdot 2,101.4$ and $78 \mathrm{~g}$, respectively) or at lunch (129.2, 94.7 and $66.4 \mathrm{~g}$, respectively).

Table 2 shows the mean daily intakes of red meat, white meat and processed meat in consumers. Men consumed significantly more $(P<0.001)$ red meat, white meat and processed meat than women. In men, 18-35-year-olds consumed significantly less $(P<0 \cdot 01)$ red meat than $>35$-year-olds and the percentage of consumers was highest in 51-64-year-olds. The percentage of consumers of white meat was lowest in 51-64-year-olds. In men, 18-35-yearolds consumed significantly more $(P<0.01)$ processed meat than $>35$-year-olds, and had the highest percentage of consumers.

\section{Nutrient intakes}

Table 3 compares the nutrient density of the diets of non-consumers and consumers across the three levels of red meat intake. When expressed as a percentage of food energy, the intake of protein was significantly highest $(P<0.001)$ and the intake of carbohydrate was significantly lowest $(P<0 \cdot 001)$ in high consumers of red meat in men and women. In men, the mean intakes $(\mathrm{g} / 10 \mathrm{MJ})$ of NSP were significantly higher $(P<0.001)$ for non-consumers. The mean intakes $(\mathrm{mg} / 10 \mathrm{MJ})$ of $\mathrm{Ca}$ were significantly higher $(P<0 \cdot 001)$ in non-consumers, whereas the intakes of $\mathrm{Zn}$ were significantly higher in high consumers for men and women. In men the intake of vitamin $B_{12}$ was significantly higher in high consumers.

Overall, the nutrient densities of the diets of non-consumers and consumers across the three levels of white meat intake were similar. The intake of protein was significantly higher $(P<0.001)$ for men and women, and the intake of carbohydrate was significantly lower $(P<0.01)$ for men, in high consumers of white meat. The mean intake of niacin was significantly higher $(P<0.01)$ for men and women in high consumers (data not shown).

Table 4 compares the nutrient density of the diets of non-consumers and consumers across the three levels of processed meat intake. The intakes of protein, carbohydrate and NSP were significantly lower $(P<0 \cdot 01)$ and the intakes of fat were significantly higher $(P<0.001)$ in high consumers of processed meat compared with non-consumers for both men and women. The intakes (unit/ $10 \mathrm{MJ}$ ) of $\mathrm{Ca}$ (women only), $\mathrm{Mg}$ and vitamin $\mathrm{D}$ were significantly lower $(P<0 \cdot 001)$ in high consumers, while the intakes of thiamine, niacin (women only), vitamin $\mathrm{B}_{6}$ (women only) and folate (men only) were significantly higher $(P<0 \cdot 01)$ in non-consumers.

\section{Compliance with population goals and adequacy of micronutrient intakes}

The proportions of compliers with population goals for macronutrient and fibre intakes in non-consumers and across thirds of red meat and processed meat intakes are shown in Table 5. In men increased red meat consumption was associated with a significant decrease $(P<0.01)$ in the proportion of compliers with the carbohydrate goal. There was also a significant decrease in the proportion of compliers with the carbohydrate goal with an increase in white meat intake in men and women (data not shown). Increased processed meat consumption was associated with significant decreases $(P<0 \cdot 01)$ in the proportion of compliers with the total fat, saturated fat, monounsaturated fat, carbohydrate and fibre goals in men, and saturated and monounsaturated fat goals in women.

Table 6 shows the prevalence of inadequate micronutrient intakes in non-consumers and cross thirds of red meat and processed meat 


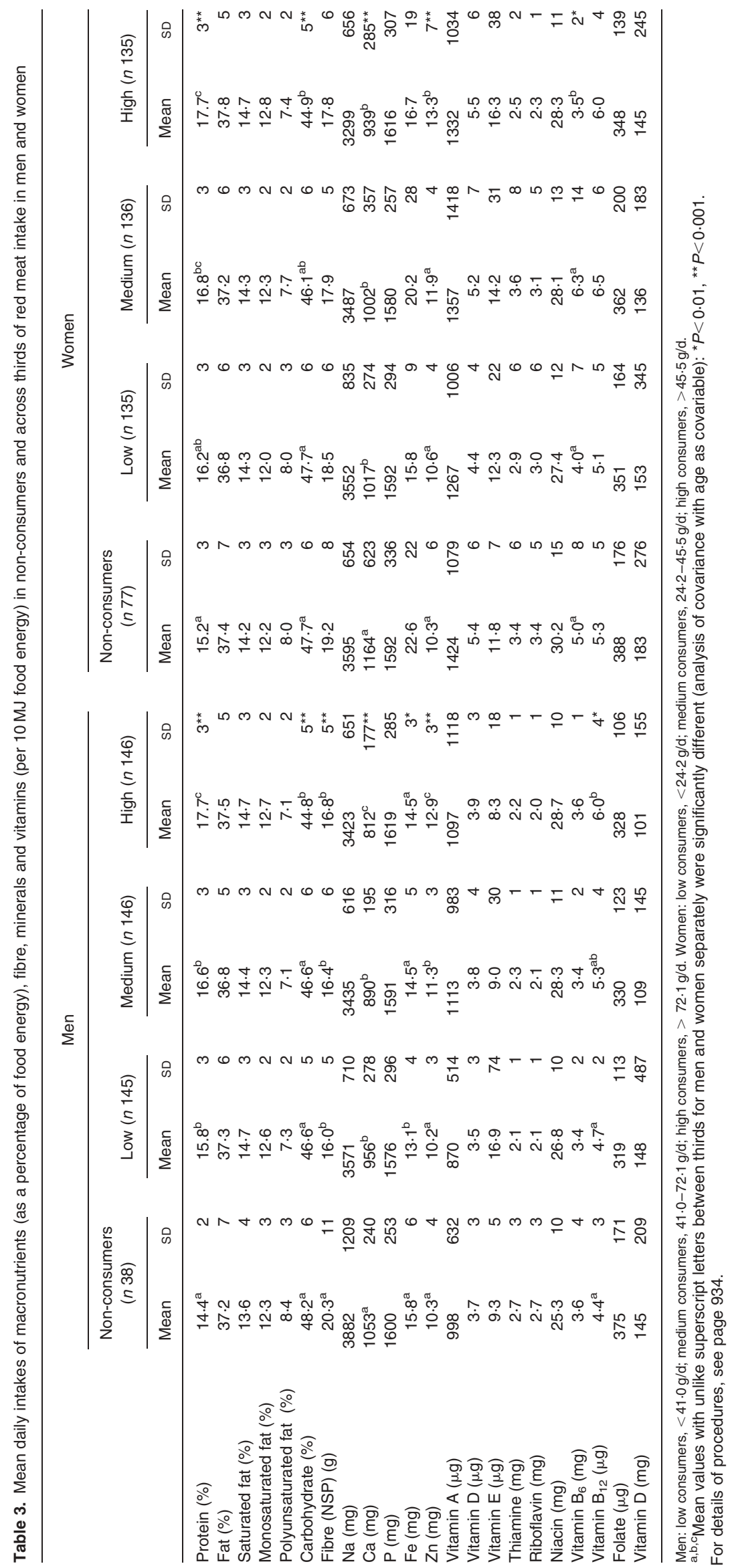




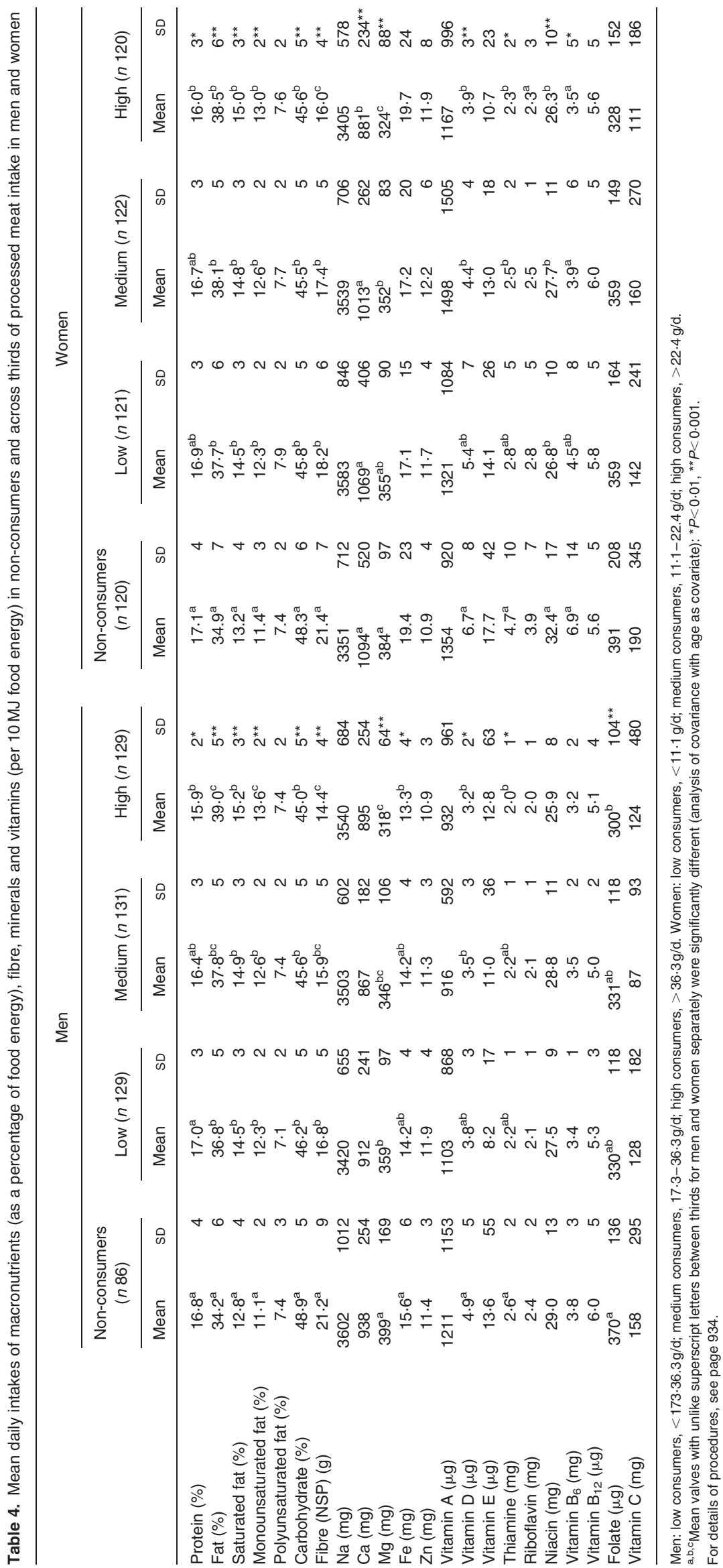



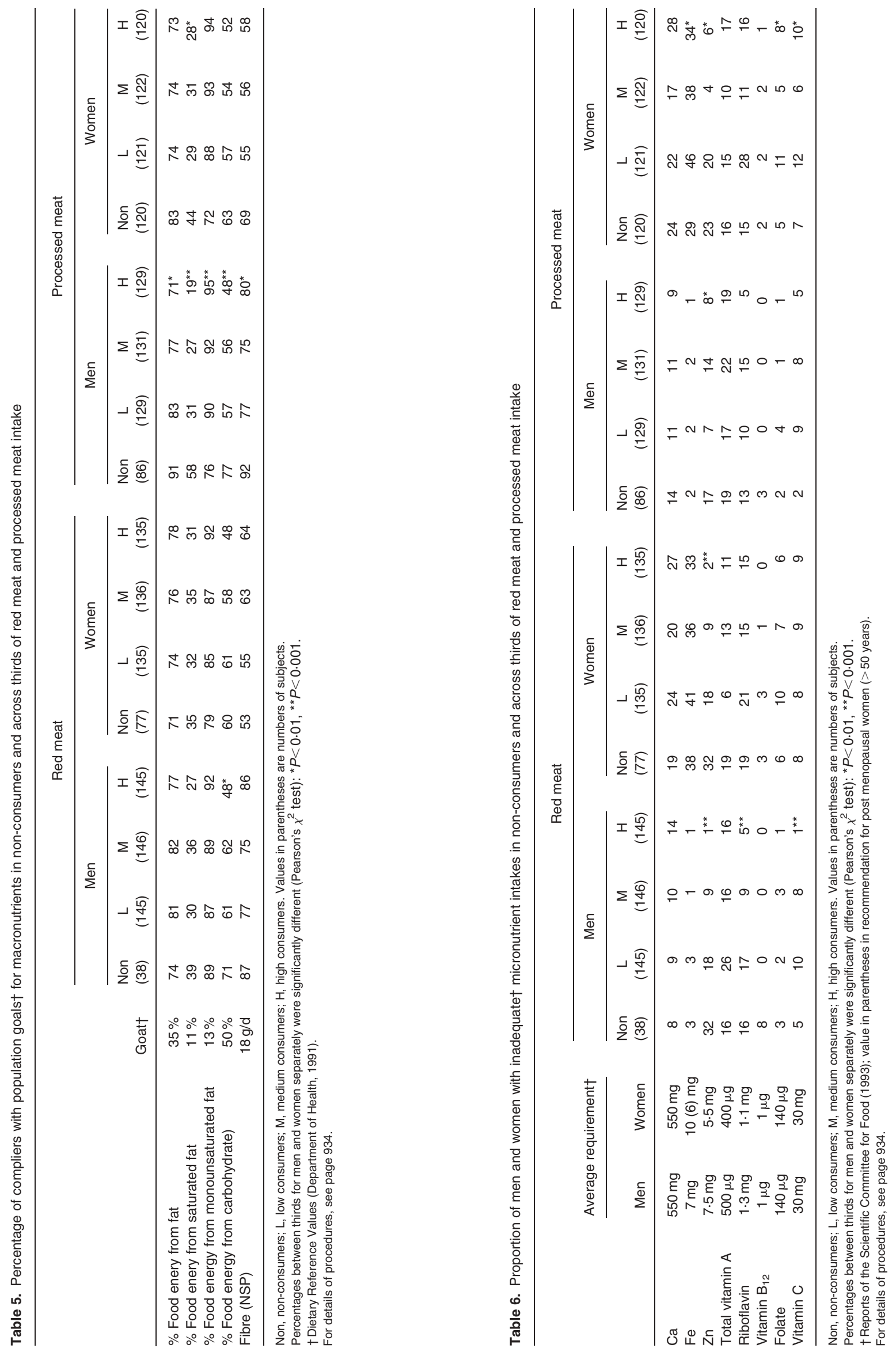
intakes. Increased red meat consumption was associated with a significantly $(P<0.001)$ lower prevalence of inadequate intakes of $\mathrm{Zn}$ in men and women and of riboflavin and vitamin $\mathrm{C}$ in men. Increased consumption of white meat was associated with a significantly lower $(P<0 \cdot 01)$ prevalence of inadequate $\mathrm{Cu}$ intakes in women (data not shown). Increased processed meat consumption was associated with a significantly lower $(P<0 \cdot 01)$ prevalence of inadequate $\mathrm{Zn}$ intakes. In women, low compared with high consumers of processed meat had a significantly higher $(P<0 \cdot 01)$ prevalence of inadequate $\mathrm{Fe}$ intakes.

\section{The influence of meat on food intake}

In men and women, there was an increase $(P<0.01)$ in potato and a decrease in processed meat intake with increasing red meat intakes, while in men there were also increases in vegetable and alcoholic beverage intakes with increasing red meat intakes $(P<0.01$; data not shown). High white meat intake was associated with significantly lower $(P<0.01)$ intakes of white bread, potatoes and red meat in men, and lower $(P<0.01)$ intakes of cheese, butter and red meat in women, compared with low and non-consumers (data not shown). High consumers of processed meat had significantly lower $(P<0 \cdot 001)$ intakes of wholemeal bread, vegetables, fruit and fish, and significantly higher $(P<0.001)$ intakes of carbonated beverages, compared with low and non-consumers. In men, the intakes of biscuits, cakes and pastries, and red meat were significantly lower in high consumers compared with non-consumers. In women the intakes of ready-to-eat breakfast cereals, yoghurts and white meat were significantly lower in high consumers compared with non-consumers.

\section{Sociodemographic, health and lifestyle factors}

Over half of men ( $58 \%$ ) and women (52\%) who did not consume red meat had tertiary-level educational qualifications compared with only a quarter of high consumers $(P<0.001)$. A higher proportion of non-consumers (55 and $61 \%$ ) than of high consumers (25 and $41 \%$ ) of processed meat had professional, managerial and technical occupations in men and women, respectively $(P<0$.001). In women, a higher proportion of high consumers compared with non-consumers of processed meat were smokers $(P<0 \cdot 01)$.

\section{Discussion}

The present paper examines the habitual intakes of meat and meat products in Irish adults as three individual meat groups. Red meat, white meat and processed meat are examined at upper and lower ends of the distribution of intakes in relation to nutrient profiles and concurrent food intakes. Investigating current patterns of meat intake is important in epidemiological studies and is an important step in the development of food-based dietary guidelines. Relative to total meat intake, red meat was consumed in the largest $(51 \mathrm{~g} / \mathrm{d}$ or $118 \mathrm{~g} /$ eating occasion) and processed meat in the smallest quantity ( $26 \mathrm{~g} / \mathrm{d}$ or $56 \mathrm{~g} /$ eating occasion). In studies of dietary intake and nutritional epidemiology, meat and meat products are generally examined as one homogeneous food group. However, the present report has shown that this approach may not be appropriate due to the diverse dietary trends and variation across different indicators of dietary quality observed in consumers at different levels of intake of red meat, white meat and processed meat.
The estimates of meat intake were obtained in a representative sample of 18-64-year-old adults from the Republic of Ireland, using the North/South Ireland Food Consumption Survey (Irish Universities Nutrition Alliance, 2001). Furthermore, non-response, investigated in terms of sex, age and geographical location, was found to be unbiased (Kiely et al. 2001). Interpretation of results from food consumption databases is prone to potential sources of bias (Leclercq \& Arcella, 2001). However, the duration of dietary assessment in the North/ South Ireland Food Consumption Survey was $7 \mathrm{~d}$, which reduced inter-individual variability that occurs in shorter surveys (Lambe \& Kearney, 1999). A hierarchical approach to food and drink quantification was developed and the food composition database was extended to include generic Irish foods and new foods on the market (Harrington et al. 2001a). Excluding energy under-reporters from the analysis did not significantly affect the outcomes. Therefore, it is valid to extrapolate conclusions from this analysis to the population as a whole and use the data for the development of national food-based dietary guidelines.

High consumers of red meat had higher protein intakes, lower carbohydrate intakes, lower compliance with carbohydrate intake recommendations and a less fibre-dense diet than did non-consumers. Previous studies have shown that low consumers of meat have diets higher in carbohydrate and fibre and lower in energy, fat and protein (Slattery et al. 1991; Nicklas et al. 1995; Elmstahl et al. 1999). Although processed meat was consumed in relatively small quantities, increased processed meat consumption was associated with an increase in the percentage of food energy from fat, a decrease in the percentage of food energy from carbohydrate and protein, and a less fibre-dense diet. Processed meat consumption was also associated with a lower level of compliance with fat, carbohydrate and fibre recommendations, particularly in men. Comparing compliance with dietary recommendations in male consumers and non-consumers of processed meat respectively, $29 \%$ and $9 \%$ did not comply with fat, $52 \%$ and $23 \%$ did not comply with carbohydrate and $22 \%$ and $8 \%$ did not comply with fibre goals.

The results suggest that red meat consumption is associated with a micronutrient-dense diet, as red meat consumers had higher $\mathrm{Zn}$, niacin and vitamin $\mathrm{B}_{12}$ intakes than did non-consumers and high consumers had higher Fe intakes than low consumers. Red meat consumers also had a lower prevalence of inadequacy of micronutrient intakes particularly for $\mathrm{Fe}, \mathrm{Zn}$, vitamin $\mathrm{A}$, riboflavin and vitamins $\mathrm{B}_{6}, \mathrm{~B}_{12}$ and $\mathrm{C}$. There were no differences in micronutrient intakes between white meat consumers and nonconsumers; however, in women, white meat consumers had a lower prevalence of inadequacy of $\mathrm{Cu}$ intakes. On the other hand, processed meat consumption was associated with lower micronutrient intakes and higher levels of inadequacy of $\mathrm{Fe}$, folate and vitamin C intakes, particularly among women. Subar et al. (1998) showed that meat was among the top ten sources of twelve micronutrients and this was primarily due to beef (top five contributor to ten micronutrients).

To help explain the different associations observed with nutrient quality within subgroups of red meat, white meat and processed meat intakes, associations with other food groups were examined. The most significant food associated with red meat consumers was potatoes, where high consumers compared with low and nonconsumers had significantly higher potato intakes. Compared with non-consumers, white meat consumers had lower potato and 
higher rice and pasta intakes, particularly in men. Differences between non-consumers and consumers of processed meat were found in the intakes of wholemeal and brown bread, ready-to-eat breakfast cereals, yoghurts, vegetables, fruit and fish. These food groups were consumed in lower quantities among processed meat consumers, particularly high consumers. Several studies have highlighted that foods such as fruit, high-fibre breakfast cereals, wholemeal bread, vegetables and fish are healthy owing to their impact on dietary quality (Galvin et al. 2003; Newby et al. 2003) and their influence on disease risk (Hu et al. 2000; Joshipura et al. 2001; Hu \& Willett, 2002; Hung et al. 2003; Steffen et al. 2003). The main source of red meat, white meat and processed meat throughout the day was at the main meal. Further research is needed to identify the convergence of foods within the main meal; however, results suggest that the consumers of processed meat make consistently poor dietary choices.

Increasing intakes of red meat were associated with lower levels of educational attainment and lower social class occupations. Those with tertiary educational qualifications or with professional and managerial occupations were less likely to be high consumers of red meat. These findings are consistent with the perceived healthiness of excluding red meat from the diet (Lea \& Worsley, 2002). In relation to processed meat, a smaller proportion of consumers than non-consumers had managerial, professional and technical occupations. Previous analysis of the current database has shown that there is a positive relationship between high social class occupations and consumption of health-promoting foods such as ready-to-eat breakfast cereals and vegetables (Galvin et al. 2003; O'Brien et al. 2003). Similarly, in this study there was a negative relationship between low social class occupations and consumption of nutrient-poor foods such as processed meat. These findings add more evidence to the theory that high social class groups eat more healthy foods, and thus have a higher chance of consuming a more health-promoting diet.

The present study has demonstrated clearly that not all meat types make similar contributions to the diet. While red meat consumption was associated with reduced compliance with dietary recommendations for carbohydrate, consumers had relatively high intakes of micronutrients, particularly $\mathrm{Cu}, \mathrm{Zn}$, thiamine, riboflavin, niacin, and vitamins $\mathrm{B}_{6}$ and $\mathrm{B}_{12}$. On the other hand, processed meat consumption was associated with low compliance with recommended fat, carbohydrate and fibre intakes, and poor adequacy of micronutrient intakes. Overall, consumption of processed meat at relatively moderate levels may be an indicator of poor overall dietary quality in the Irish adult population, as evidenced by the negative association of increasing processed meat intake with nutrient-dense food intakes. These results emphasise the importance of considering distinct subgroups of major food categories (e.g. dairy foods, meat and cereals) and the overall diet in studies of dietary modification of disease risk. Programmes for improving dietary quality in terms of meat intake should highlight individual meat groups and target in particular young adults (especially men), those with a lower level of educational attainment and those in lower socio-economic groups, as these groups are more likely to be high consumers of processed meat.

\section{References}

Carriquiry AL (1999) Assessing the prevalence of nutrient inadequacy Public Health Nutr 2, 23-33
Central Statistics Office (1997) Census '96 Principal Demographic Results. Dublin: Government of Ireland.

Central Statistics Office (1998) Census '96 Principal Socio-economic Results. Dublin: Government of Ireland.

Chan W, Brown J \& Buss DH (1994) Miscellaneous Foods. Fourth supplement to McCance and Widdowson's The Composition of Foods, 5th ed. Royal Society of Chemistry and Ministry of Agriculture, Fisheries and Food. London: HMSO.

Chan W, Brown J, Lee SM \& Buss DH (1995) Meat, Poultry and Game. Fifth supplement to McCance and Widdowson's The Composition of Foods, 5th ed. Royal Society of Chemistry and Ministry of Agriculture, Fisheries and Food. London: HMSO.

Chan W, Brown J, Church SM \& Buss DH (1996) Meat Products and Dishes. Sixth supplement to McCance and Widdowson's The Composition of Foods, 5th ed. Royal Society of Chemistry and Ministry of Agriculture, Fisheries and Food. London: HMSO.

Chen H, Ward MH, Graubard BI, Heineman EF, Markin RM, Potishman NA, Russell RM, Weisenburger DD, \& Tucker KL (2002) Dietary patterns and adenocarcinoma of the esophagus and distal stomach. Am J Clin Nutr 75, 137-144.

Cosgrove M, Flynn A \& Kiely M (2005) Impact of disaggregation of composite foods on estimates of intakes of meat and meat products in Irish adults. Public Health Nutr 8, 327-337.

Denke MA (1994) Role of beef and beef tallow, an enriched source of stearic acid, in a cholesterol-lowering diet. Am J Clin Nutr 60, Suppl. $6,1044 \mathrm{~S}-1049 \mathrm{~S}$.

Department of Health (1991) Dietary Reference Values for Food Energy and Nutrients for the United Kingdom. Report of the Panel on Dietary Reference Values of the Committee on Medical Aspects of Food Policy. London: HMSO.

Elmstahl S, Holmqvist O, Gullberg B, Johansson U \& Berglund G (1999) Dietary patterns in high and low consumers of meat in a Swedish cohort study. Appetite 32, 191-206.

Food and Agriculture Organization/World Health Organization (1998) Preparation and Use of Food-based Dietary Guidelines. Report of a Joint FAO/WHO Consultation. Technical Report Series no. 880. Geneva: WHO.

Food and Nutrition Board, Institute of Medicine (1997) Dietary References Intakes: Calcium, Phosphorus, Magnesium, Vitamin D and Fluoride. Washington, DC: National Academies Press.

Fung TT, Hu FB, Fuchs C, Giovannuci E, Hunter DJ, Stampfer MJ, Colditz GA \& Willett WC (2003) Major dietary patterns and the risk of colorectal cancer in women. Arch Intern Med 163, 309-314.

Fung TT, Willett WC, Stampfer MJ, Manson JE \& Hu FB (2001) Dietary patterns and the risk of coronary heart disease in women. Arch Intern Med 161, 1857-1862.

Galvin MA, Kiely M \& Flynn A (2003) Impact of ready-to-eat breakfast cereal (RTEBC) consumption on adequacy of micronutrient intakes and compliance with dietary recommendations in Irish adults. Public Health Nutr 6, 351-363.

Giovannucci E, Rimm EB, Stampfer MJ, Colditz GA, Ascherio A \& Willett WC (1994) Intake of fat, meat, and fiber in relation to risk of colon cancer in men. Cancer Res 54, 2390-2397.

Goldberg GR, Black AE, Jebb SA, Cole TJ, Murgatroyd PR, Coward WA \& Prentice AM (1991) Critical evaluation of energy intake data using fundamental principles of energy physiology: 1 . Derivation of cut-off limits to identify under-recording. Eur J Clin Nutr 45, 569-581.

Goldbohm RA, van den Brandt PA, van't Veer P, Brants HA, Dorant E, Sturmans F \& Hermus RJ (1994) A prospective cohort study on the relation between meat consumption and the risk of colon cancer. Cancer Res 54, 718-723.

Hannon EM, Kiely M, Harrington KE, Robson PJ, Strain JJ \& Flynn A (2001) The North/South Ireland Food Consumption Survey: mineral intakes in 18-64-year-old adults. Public Health Nutr 4, 1081-1088.

Harrington KE, McGowan MJ, Kiely M, Robson PJ, Livingstone MB, Morrissey PA \& Gibney MJ (2001a) Macronutrient intakes and food 
sources in Irish adults: findings of the North/South Ireland Food Consumption Survey. Public Health Nutr 4, 1051-1060.

Harrington KE, Robson PJ, Kiely M, Livingstone MB, Lambe J \& Gibney MJ (2001b) The North/South Ireland Food Consumption Survey: survey design and methodology. Public Health Nutr 4, 1037-1042.

Holland B, Brown J \& Buss DH (1993) Fish and Fish Products. Third supplement to McCance and Widdowson's The Composition of Foods, 5th ed. Royal Society of Chemistry and Ministry of Agriculture, Fisheries and Food. London: HMSO.

Holland B, Unwin ID \& Buss DH (1988) Cereals and Cereal Products. Third supplement to McCance and Widdowson's The Composition of Foods, 4th ed. Royal Society of Chemistry and Ministry of Agriculture, Fisheries and Food. London: HMSO.

Holland B, Unwin ID \& Buss DH (1989) Milk Products and Eggs. Fourth supplement to McCance and Widdowson's The Composition of Foods, 4th ed. Royal Society of Chemistry and Ministry of Agriculture, Fisheries and Food. London: HMSO.

Holland B, Unwin ID \& Buss DH (1991) Vegetables, Herbs and Spices. Fifth supplement to McCance and Widdowson's The Composition of Foods, 4th ed. Royal Society of Chemistry and Ministry of Agriculture, Fisheries and Food. London: HMSO.

Holland B, Unwin ID \& Buss DH (1992) Fruit and Nuts. First supplement to McCance and Widdowson's The Composition of Foods, 5th ed. Royal Society of Chemistry and Ministry of Agriculture, Fisheries and Food. London: HMSO.

Holland B, Welch AA \& Buss DH (1996) Vegetable Dishes. Second supplement to McCance and Widdowson's The Composition of Foods, 5th ed. Royal Society of Chemistry and Ministry of Agriculture, Fisheries and Food. London: HMSO.

Holland B, Welch AA, Unwin ID, Buss DH, Paul AA \& Southgate DAT (1995) McCance and Widdowson's The Composition of Foods, 5th ed. Royal Society of Chemistry and Ministry of Agriculture, Fisheries and Food. London: HMSO.

Hu FB (2002) Dietary pattern analysis: a new direction in nutritional epidemiology. Curr Opin Lipidol 13, 3-9.

Hu FB, Rimm EB, Stampfer MJ, Ascherio A, Spiegelman D \& Willett WC (2000) Prospective study of major dietary patterns and risk of coronary heart disease in men. Am J Clin Nutr 72, 912-921.

Hu FB, Stampfer MJ, Manson JE, Ascherio A, Colditz GA, Speizer FE, Hennekens CH \& Willett WC (1999) Dietary saturated fats and their food sources in relation to the risk of coronary heart disease in women. Am J Clin Nutr 70, 1001-1008.

Hu FB \& Willett WC (2002) Optimal diets for prevention of coronary heart disease. JAMA 288, 2569-2578.

Hung HC, Merchant A, Willett W, Ascherio A, Rosner BA, Rimm E \& Joshipura KJ (2003) The association between fruit and vegetable consumption and peripheral arterial disease. Epidemiology 14, 659-665.

Irish Universities Nutrition Alliance (2001) North/South Ireland Food Consumption Survey Database. Ireland: University College Cork, Trinity College Dublin, and University of Ulster at Coleraine.

Joshipura KJ, Hu FB, Manson JE, et al. (2001) The effect of fruit and vegetable intake on risk for coronary heart disease. Ann Intern Med 134, 1106-1114.

Key TJ, Schatzkin A, Willett WC, Allen NE, Spencer EA \& Travis RC (2004) Diet, nutrition and the prevention of cancer. Public Health Nutr 7, 187-200.

Kiely M, Flynn A, Harrington KE, Robson PJ \& Cran G (2001) Sampling description and procedures used to conduct the North/South Ireland Food Consumption Survey. Public Health Nutr 4, 1029-1035.

Lahti-Koski M, Pietinen P, Heliovaara M \& Vartiainen E (2002) Associations of body mass index and obesity with physical activity, food choices, alcohol intake and smoking in the 1982-1997 FINRISK studies. Am J Clin Nutr 75, 809-817.

Lambe J \& Kearney J (1999) The influence of survey duration on estimates of food intakes - relevance for food-based dietary guidelines. Br J Nutr 81, S139-S142.

Lea E \& Worsley A (2002) The cognitive contexts of beliefs about the healthiness of meat. Public Health Nutr 5, 37-45.
Leclercq C \& Arcella D (2001) Correlation analyses as a step to identify foods that are sources of inter-individual variability in nutrients; their use for the development of food based dietary guidelines. Public Health Nutr 4, 689-692.

McGowan MJ, Harrington KE, Kiely M, Robson PJ, Livingstone MB \& Gibney MJ (2001) An evaluation of energy intakes and the ratio of energy intake to estimated basal metabolic rate $\left(E I / B_{M R}\right.$ est $)$ in the North/South Ireland Food Consumption Survey. Public Health Nutr 4, 1043-1050.

Ministry of Agriculture, Fisheries and Food (1997) Food Portion Sizes. London: The Stationery Office.

Navarro A, Diaz MP, Munoz SE, Lantieri MJ \& Eynard AR (2003) Characterization of meat consumption and risk of colorectal cancer in Cordoba, Argentina. Nutrition 19, 7-10.

Newby PK, Muller D, Hallfrisch J, Qiao N, Andres R \& Tucker KL (2003) Dietary patterns and changes in body mass index and waist circumference in adults. Am J Clin Nutr 77, 1417-1425.

Nicklas TA, Farris RP, Myers L \& Berenson GS (1995) Impact of meat consumption on nutritional quality and cardiovascular risk factors in young adults: the Bogalusa Heart Study. J Am Diet Assoc 95, 887-892.

O'Brien MM, Kiely M, Galvin M \& Flynn A (2003) The importance of composite foods for estimates of vegetable and fruit intakes. Public Health Nutr 6, 711-726.

Pryer JA, Nichols R, Elliott P, Thakrar B, Brunner E \& Marmot M (2001) Dietary patterns among a national random sample of British adults. J Epidemiol Community Health 55, 29-37.

Quatromoni PA, Copenhafer DL, D'agostino RB \& Millen BE (2002) Dietary patterns predict the development of overweight in women: The Framingham Nutrition Studies. J Am Diet Assoc 102, $1239-1246$.

Scientific Committee for Food (1993) Nutrient and Energy Intakes for the European Community. Luxembourg: Office for Official Publications of the European Communities.

Schulz M, Kroke A, Liese AD, Hoffmann K, Bergmann MM \& Boeing H (2002) Food groups as predictors for short-term weight changes in men and women of the EPIC-Potsdam cohort. J Nutr 132, 1335-1340.

Sesink AL, Termont DS, Kleibeuker JH \& Van der Meer R (1999) Red meat and colon cancer: the cytotoxic and hyperproliferative effects of dietary heme. Cancer Res 59, 5704-5709.

Slattery ML, Jacobs DR Jr, Hilner JE, Caan BJ, Van Horn L, Bragg C, Manolio TA, Kushi LH \& Liu KA (1991) Meat consumption and its associations with other diet and health factors in young adults: the CARDIA study. Am J Clin Nutr 54, 930-935.

Steffen LM, Jacobs DR Jr, Stevens J, Shahar E, Carithers T \& Folsom AR (2003) Associations of whole-grain, refined-grain, and fruit and vegetable consumption with risks of all-cause mortality and incident coronary artery disease and ischemic stroke: the Atherosclerosis Risk in Communities (ARIC) Study. Am J Clin Nutr 78, 383-390.

Subar AF, Krebs-Smith SM, Cook A \& Kahle LL (1998) Dietary sources of nutrients among US adults, 1989 to 1991. J Am Diet Assoc 98, 537-547. van Dam RM, Gievink L, Ocke MC \& Feskens EJ (2003) Patterns of food consumpation and risk factors for cardiovascular disease in the general Dutch population. Am J Clin Nutr 77, 1156-1163.

van Dam RM, Rimm EB, Willett WC, Stampfer MJ \& Hu FB (2002) Dietary patterns and risk for type 2 diabetes mellitus in US men. Ann Intern Med 136, 201-209.

Wearne SJ \& Day MJ (1999) Clues for the development of food-based dietary guidelines: how are dietary targets being achieved by UK consumers? Br J Nutr 81, Suppl. 2, S119-S126.

Willett WC, Stampfer MJ, Colditz GA, Rosner BA \& Speizer FE (1990) Relation of meat, fat, and fiber intake to the risk of colon cancer in a prospective study among women. $N$ Engl J Med 323, 1664-1672.

World Cancer Research Fund/American Institute for Cancer Research (1997) Food Nutrition and the Prevention of Cancer: A Global Perspective. Washington, DC: WCRF/AICR. 